1

5

6

7

8

9

10

11

13

15

16

\title{
X-Ray Tomography Study on Porosity and Particle Size Distribution in In Situ Al-4.5Cu-5TiB 2 Semisolid Rolled Composites
}

\author{
SWAPNIL MORANKAR, ${ }^{1}$ MONALISA MANDAL,${ }^{1}$ NADIA KOURRA, ${ }^{2}$ \\ MARK A. WILLIAMS ${ }^{2}$ RAHUL MITRA, ${ }^{1}$ and PRAKASH SRIRANGAM ${ }^{2,3}$ \\ 1.-Department of Metallurgical and Materials Engineering, Indian Institute of Technology, \\ Kharagpur, West Bengal 721 302, India. 2.-WMG, University of Warwick, Coventry CV4 7AL, \\ UK. 3.-e-mail: P.Srirangam@warwick.ac.uk
}

X-ray computed tomography (XCT) was used for three-dimensional (3D) visualization of the internal microstructure and quantification of the porosity and second-phase particles in $\mathrm{Al}-4.5 \mathrm{Cu}-5 \mathrm{TiB}_{2}$ composites prepared by an in situ liquid metallurgy casting route. The as-cast composites were subjected to hot rolling and mushy-state rolling for deagglomeration and to achieve a uniform distribution of $\mathrm{CuAl}_{2}-\mathrm{TiB}_{2}$ particle clusters. Qualitative results obtained by scanning electron microscopy (SEM) and quantitative results obtained by XCT both showed that mushy-state rolling as well as hot rolling resulted in fragmentation and a homogeneous distribution of the $\mathrm{CuAl}_{2}-\mathrm{TiB}_{2}$ particle clusters, with the mushy-state-rolled composite exhibiting the highest number of smaller-size particles. The porosity was increased in both rolling conditions through debonding of particles due to the compressive force during solid-state deformation along with the quick solidification of the solute-rich liquid during mushy-state rolling. These results show that application of secondary processes such as hot-rolling and mushy-state rolling can help to achieve a relatively more uniform particle distribution in $\mathrm{Al}-4.5 \mathrm{Cu}-5 \mathrm{TiB}_{2}$ in situ composites.

\section{INTRODUCTION}

The demand for lightweight composite materials is increasing in automotive and aerospace applications to reduce fuel consumption and greenhouse gas emissions. ${ }^{1} \mathrm{Al}-\mathrm{Cu}$ alloy-based metal-matrix composites (MMCs) have found wide applications in the automobile industry owing to their high specific strength, reasonable ductility, and excellent wear resistance, which make them suitable for applications involving sliding wear and high-strength loadbearing parts. ${ }^{1,2,4-13}$ Over the last decade, $\mathrm{TiB}_{2}$-reinforced $\mathrm{Al}-\mathrm{Cu}$ MMCs have attracted significant interest. ${ }^{3,5-7,9} \mathrm{TiB}_{2}$ has excellent properties as a reinforcement particle, such as high hardness (960 $\mathrm{HV}$ ), high elastic modulus (530 GPa), and high melting point $\left(2790^{\circ} \mathrm{C}\right),{ }^{13,14}$ and most importantly does not react with the $\mathrm{Al}$ matrix even at very high temperatures. ${ }^{8,15}$ Furthermore, $\mathrm{TiB}_{2}$ particles can act as nucleating sites for primary aluminum, resulting in grain refinement of the alloy by pinning grain boundaries when added at low levels, while it also acts as a particulate reinforcement when added at higher proportions, changing metal alloys to metal-matrix composites. ${ }^{16}$

Although MMCs can be prepared by adding reinforcement particles externally to a molten metal matrix, this approach suffers from various problems such as weak interfacial bonding, poor wettability, as well as agglomeration and an inhomogeneous distribution of particles, which ultimately degrade the mechanical properties. ${ }^{12}$ These problems led to the development of in situ $\mathrm{Al}-\mathrm{Cu}-\mathrm{TiB}_{2}$ composites processed by a liquid metallurgy route using $\mathrm{K}_{2} \mathrm{TiF}_{6}$ and $\mathrm{KBF}_{4}$ salts. $^{3-7}$ However, these salt reactions result in an inhomogeneous distribution of in situ submicron-sized $\mathrm{TiB}_{2}$ particles, as the particles tend to form clusters which deteriorate the mechanical properties of the composites..$^{10,17-19}$ It has also been observed that submicron-sized $\mathrm{TiB}_{2}$ particles are

\begin{tabular}{|l|lll|}
\hline & Journal : 11837_JOM & Dispatch : 27-2-2019 & Pages : 9 \\
& & $\square$ LE & $\square$ TYPESET \\
\hline
\end{tabular}


pushed towards grain boundaries during solidification. ${ }^{20}$ Secondary processes such as extrusion, rolling, forging, mushy-state rolling, or mushy-state forging can help to achieve a uniform distribution of particulate reinforcement in a metal matrix. ${ }^{8,20,22,23}$ Hot rolling helps to achieve a uniform distribution of particles and also refines the grains by dynamic recrystallization. ${ }^{21-23}$ Another secondary process which has attracted remarkable attention over the last few years is mushy-state rolling. In mushy state, the presence of liquid component at grain boundaries reduces the force required for deformation. It also allows rotation and sliding of solid grains, which ultimately increases the formability of the composite. ${ }^{24,25}$ Herbert et al. $^{9}$ reported that irregular-rosette-shaped grains were modified to globular or equiaxed grains in mushy-state rolling. Previous research has shown that mushy-state rolling not only results in a more uniform distribution of particles but also improves the hardness, tensile properties, wear resistance, and aging kinetics of in situ $\mathrm{Al}-4.5 \mathrm{Cu}-5 \mathrm{TiB}_{2}$ composites. $^{2,5,6,9,26,27}$

Understanding of the particle distribution and porosity formation is essential to reduce defects and improve the mechanical properties of composites. Two-dimensional image-based techniques such as optical and scanning electron microscopy can provide quantitative information on microstructural features but require innumerable images and serial sectioning of the sample, which is a challenging task. X-ray computed tomography (XCT) is a nondestructive technique which enables three-dimensional (3D) visualization of microstructural features such as the porosity and particle distribution in alloy composites. ${ }^{28-38}$ Hamilton et al. ${ }^{39}$ used XCT to quantify the $\mathrm{TiB}_{2}$ particles in aluminum metalmatrix composite. Watson et al. ${ }^{32}$ studied the clustering behavior of $\mathrm{TiB}_{2}$ particles in $\mathrm{Al}$ and observed a reduction in the number of larger clusters with holding at $700^{\circ} \mathrm{C}$ due to dissolution of $\mathrm{Al}_{3} \mathrm{Ti}$ phase present between adjacent particles. Chen et al. ${ }^{17}$ used XCT to study the agglomeration behavior of $\mathrm{TiB}_{2}$ particles in aluminum. Recently, Mathew et al. ${ }^{19}$ investigated the variation of the porosity and particle distribution in as-cast and semisolid-forged $\mathrm{Al}-\mathrm{Cu}-\mathrm{TiB}_{2}$ composites using XCT. However, to date, no XCT study was found in literature on the porosity and particle size distribution in mushystate-rolled $\mathrm{Al}-4.5 \mathrm{Cu}-5 \mathrm{TiB}_{2}$ in situ composites. In the work presented herein, we investigated the porosity and particle size distribution of $\mathrm{Al}-4.5 \mathrm{Cu}-$ $5 \mathrm{TiB}_{2}$ in situ composites processed under different rolling conditions using the $3 \mathrm{D} \mathrm{XCT}$ technique.

\section{EXPERIMENTAL PROCEDURES}

\section{Processing of $\mathrm{Al}-4.5 \mathrm{Cu}-5 \mathrm{TiB}_{2}$ Composites}

In situ $\mathrm{Al}-4.5 \mathrm{Cu}-5 \mathrm{TiB}_{2}$ composites were prepared by a liquid metallurgy route. Initially, $\mathrm{Al}-33$ wt. $\% \mathrm{Cu}$ master alloy was melted, and commercially pure $\mathrm{Al}$ was added to the melt in an appropriate amount to achieve the composition Al-4.5 wt.\%Cu. Subsequently, halide salts $\mathrm{K}_{2} \mathrm{TiF}_{6}$ and $\mathrm{KBF}_{4}$ were added into the melt at $800^{\circ} \mathrm{C}$ in stoichiometric ratio to form in situ $\mathrm{TiB}_{2}$ particles. The melt was held for $1 \mathrm{~h}$ and stirred intermittently every $10 \mathrm{~min}$ for particles to be distributed uniformly in the matrix. The as-cast samples were subjected to different rolling conditions. Hot rolling was carried out at $370^{\circ} \mathrm{C}$. Mushystate rolling was carried out at $626^{\circ} \mathrm{C}$, which is the temperature corresponding to $20 \mathrm{vol} . \%$ liquid. ${ }^{6}$ The rolled samples were water-quenched to prevent any compositional or microstructural changes. The thickness reduction was kept constant up to $5 \%$ in all cases to avoid the problem of alligatoring. ${ }^{6} \mathrm{~A}$ portable furnace was kept near to the rolling mill to prevent heat loss.

\section{D Characterization Using SEM}

Two-dimensional (2D) characterization was carried out by field-emission scanning electron microscopy (FESEM, Merlin, Carl Zeiss SMT GmbH, Oberkochen, Germany). All samples were mechanically polished following standard metallographic procedures and observed by SEM in secondaryelectron (SE) mode. Images were recorded at higher magnification for better visualization of the microstructure. The chemical composition of individual phases was investigated simultaneously using energy-dispersive $\mathrm{x}$-ray analysis (EDAX) in SEM.

\section{D X-Ray Computed Tomography}

$\mathrm{X}$-ray tomography studies were performed using a Zeiss Versa 520 at WMG, University of Warwick, UK. Table I presents the XCT machine details, software, and optimum scanning parameters used in the present study. The voxel resolution of the scans was $514 \mathrm{~nm}$. The achieved resolution provides the required information based on the particle sizes. The scanning parameters were selected according to the grey values of radiographs to provide sufficient penetration while minimizing noise. Radiation filtration was used to minimize beam hardening and cupping artifacts. A further beam hardening reduction algorithm was used during the reconstruction of the $2 \mathrm{D}$ radiographs. The reconstructed $3 \mathrm{D}$ volume was segmented utilizing a label marked technique to separate matrix material, particles, and pores. The different segments were then statistically analyzed and represented in $3 \mathrm{D}$ to demonstrate their distribution and interference.

\section{RESULTS AND DISCUSSION}

Figure 1 shows SEM images of the as-cast Al$4.5 \mathrm{Cu}-5 \mathrm{TiB}_{2}$ composite (ACC) along with EDAX maps depicting the elemental distribution as well as SEM images of the hot-rolled composite (HRC) and mushy-state-rolled composite (MRC). As shown in

\begin{tabular}{|l|lll|}
\hline & Journal : 11837_JOM & Dispatch : 27-2-2019 & Pages : 9 \\
& & $\square$ LE & $\square$ TYPESET \\
\hline
\end{tabular}


X-Ray Tomography Study on Porosity and Particle Size Distribution in In Situ Al-4.5Cu-5TiB 2 Semisolid Rolled Composites

Table I. Machine, software packages, and XCT scanning parameters used in this study

\begin{tabular}{|c|c|c|c|}
\hline Machine and software used & Name & Producer & Year \\
\hline X-ray CT scanner & Zeiss Versa 520 & Carl Zeiss AG & 2015 \\
\hline CT scanning software & Scout and Scan Control System & Carl Zeiss AG & 2018 \\
\hline CT reconstruction software & Scout and Scan Reconstructor & Carl Zeiss AG & 2018 \\
\hline Analysis software & Avizo 9.4 & FEI Visualisation Science Group & 2017 \\
\hline
\end{tabular}

XCT scanning parameters

Voltage $(\mathrm{kV})$

Power (W)

Exposure time (s)

Optical magnification

Voxel size (nm)

Filter $\left(\mathrm{mm} \mathrm{SiO}_{2}\right)$
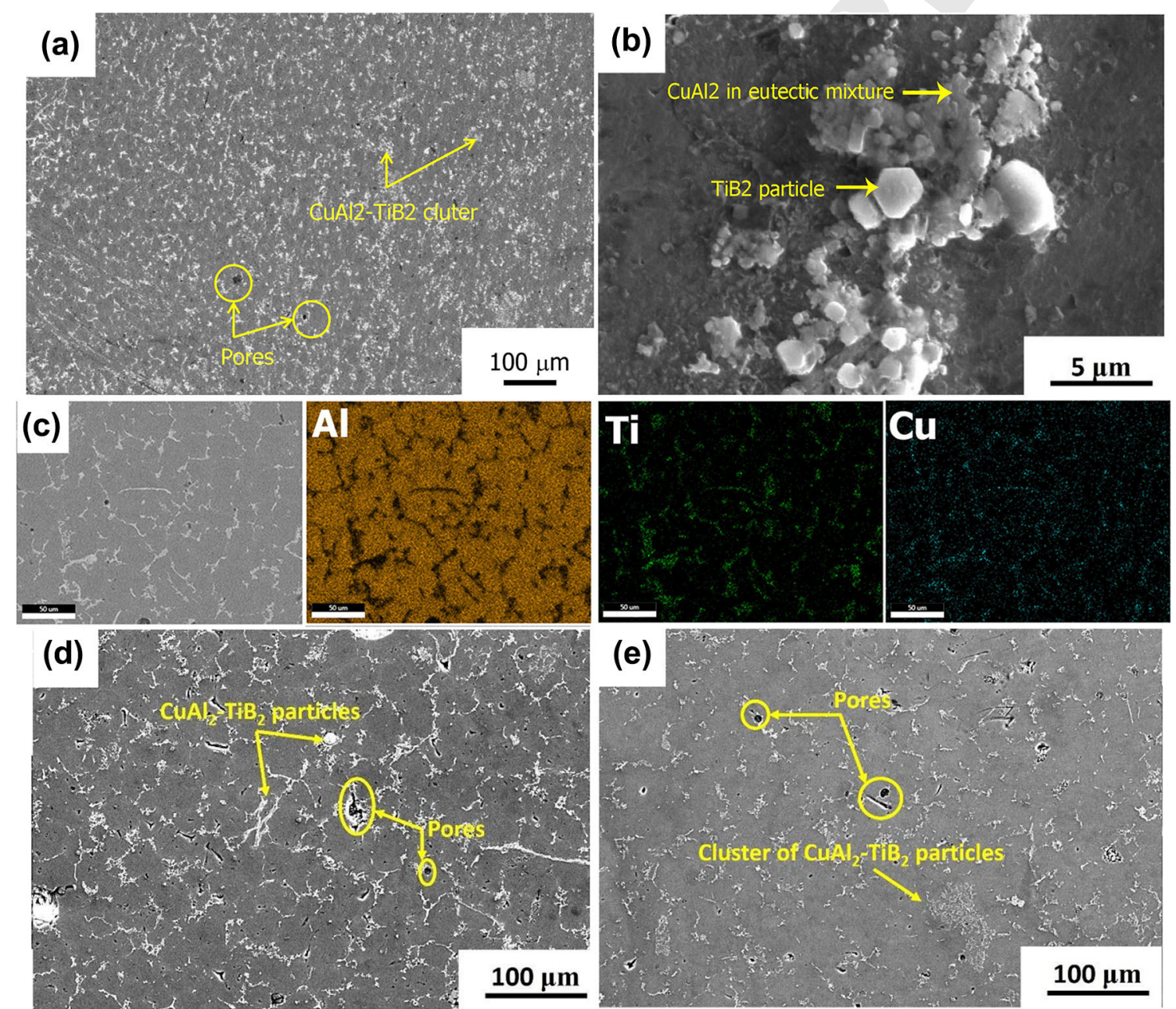

Fig. 1. SEM micrographs of $\mathrm{Al}-4.5 \mathrm{Cu}-5 \mathrm{TiB}_{2}$ composites in (a) as-cast sample and (b) magnified view of second-phase particles at grain boundary in as-cast composite; (c) EDAX elemental maps of as-cast microstructure; (d) SEM image of hot-rolled composite; (e) SEM image of mushy-state-rolled composite.

187 Fig. 1a, the as-cast composite exhibited a rosette188 shaped grain structure with second-phase particle 189 clusters distributed nonuniformly at grain bound- aries and triple-grain junctions. Previous phase identification of this particular composite by XRD technique revealed only $\mathrm{Al}, \mathrm{CuAl}_{2}$, and $\mathrm{TiB}_{2}$ pha-

\begin{tabular}{|l|lll|}
\hline \multirow{2}{*}{ Journal : 11837_JOM } & Dispatch : 27-2-2019 & Pages : $\mathbf{9}$ \\
& & $\square$ LE & $\square$ TYPESET \\
& Article No.: 3385 & $\square$ CP & $\varangle$ DISK \\
\hline
\end{tabular}



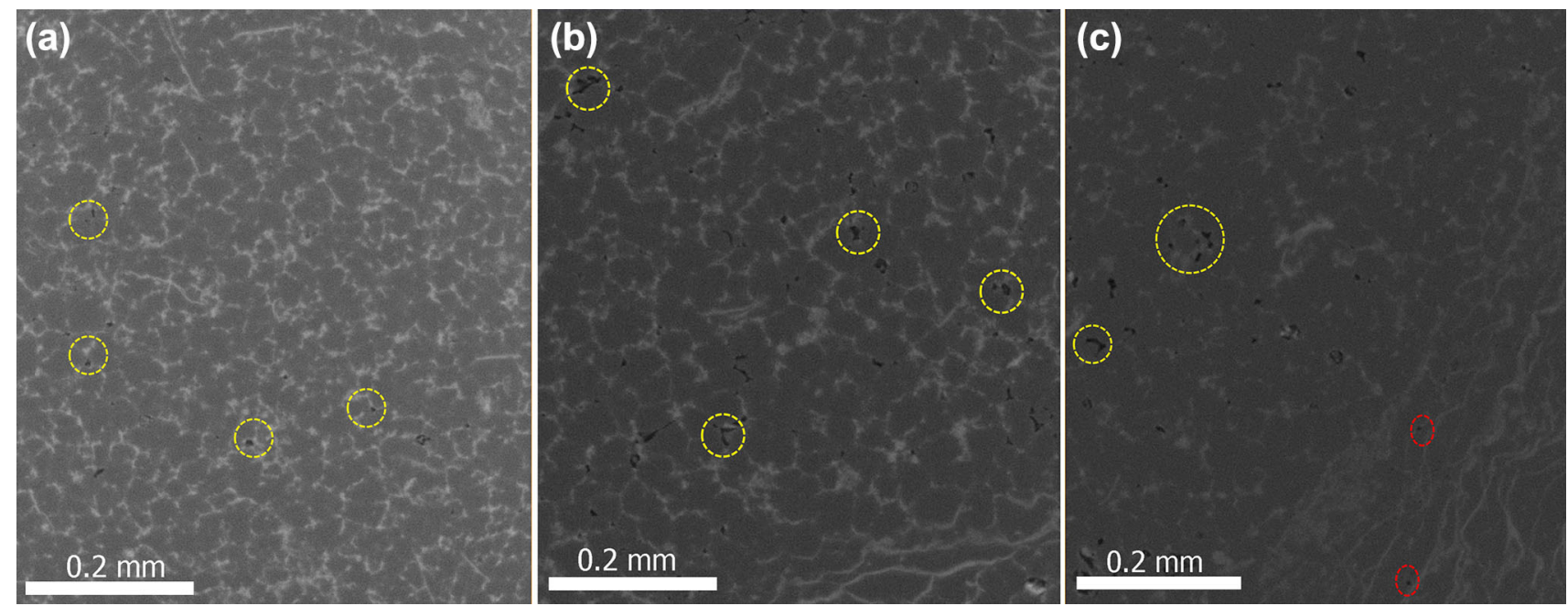

Fig. 2. Orthogonal slices of $\mathrm{Al}-4.5 \mathrm{Cu}-5 \mathrm{TiB}_{2}$ composites showing $\mathrm{CuAl}_{2}-\mathrm{TiB}_{2}$ particle cluster distribution along with porosities in (a) as-cast, (b) hot-rolled, and (c) mushy-state-rolled conditions.

ses. ${ }^{6}$ The high-magnification image of the particle clusters in Fig. $1 \mathrm{~b}$ reveals hexagonal $\mathrm{TiB}_{2}$ particles (diameter from $0.2 \mu \mathrm{m}$ to $1.5 \mu \mathrm{m}$ ) accompanied by $\mathrm{CuAl}_{2}$-eutectic mixture in intergranular regions. The EDAX elemental distribution maps further confirm this and the presence of $\mathrm{TiB}_{2}-\mathrm{CuAl}_{2}$ particles together based on the $\mathrm{Cu}$ and $\mathrm{Ti}$ enrichment observed at the grain boundaries in Fig. 1c. The coexistence of $\mathrm{CuAl}_{2}-\mathrm{TiB}_{2}$ particle clusters at the grain boundaries of the MRC sample was reported previously based on a phase map generated by electron backscatter diffraction (EBSD) analysis. ${ }^{6}$ Hot rolling at $370^{\circ} \mathrm{C}$ led to fragmentation of these clusters (Fig. 1d). The clusters of $\mathrm{CuAl}_{2}-\mathrm{TiB}_{2}$ particles are homogeneously distributed along grain boundaries. Mushy-state rolling at $626^{\circ} \mathrm{C}$ resulted in further fragmentation of these clusters, as shown in Fig. 1e. Such redistribution of particle clusters along grain boundaries in hot rolling can be attributed to multiple phenomena such as fragmentation and redistribution of particle clusters due to compressive force or particle-stimulated recrystallization at the time of hot rolling, as the hot-rolling temperature is almost 0.69 times the melting temperature of pure $\mathrm{Al}$. In contrast, in mushy-state rolling, liquid present at intergranular locations aids in the distribution of particles by viscous dragging in addition to solid-state deformation. Furthermore, the second-phase particles, being sites of strain concentration, stimulate nucleation of recrystallized $\mathrm{Al}$ grains, as also reported in previous publications. ${ }^{40}$

Figure 2 shows two-dimensional orthogonal slices of as-cast and rolled $\mathrm{Al}-4.5 \mathrm{Cu}-5 \mathrm{TiB}_{2}$ composites obtained from XCT measurements. Based on the density differences among the phases present within the microstructure, the $\mathrm{Al}$ phase appears as dark grey whereas the $\mathrm{CuAl}_{2}-\mathrm{TiB}_{2}$ particle clusters together appear as bright grey, and the porosities appear as black in Fig. 2. As shown in Fig. 2a, clusters of $\mathrm{CuAl}_{2}-\mathrm{TiB}_{2}$ particles and porosities (marked with yellow dotted circles) are present in the as-cast composite. Figure $2 \mathrm{~b}$ presents the orthogonal slice of the hot-rolled composite, showing a network of $\mathrm{CuAl}_{2}-\mathrm{TiB}_{2}$ particle clusters along grain boundaries. Porosities are primarily observed because of debonding of particles, as shown by circles in the image, which can be attributed to fragmentation of particles due to the compressive force during rolling. A similar type of porosities, along with some very fine-sized porosities (marked by red dotted circles), were observed in case of the MRC (Fig. 2c). Mushy-state rolling resulted in significant fragmentation of particle clusters (Fig. 2c), while some particles became arranged in river-like patterns. This could be due to the drag of liquid present at intergranular locations in mushy-state rolling. Careful observation of Fig. 2c suggests that the very fine-sized porosity at the river-like pattern in MRC can be attributed to solidification defects of the solute-rich viscous liquid. Qualitative observation of Fig. 2 suggests that the porosity increased in the hot-rolled as well as mushy-state-rolled composite. Possible reasons for such behavior are discussed in the next sections.

Figure $3 a-c$ shows the segmented volumes of the $\mathrm{Al}-4.5 \mathrm{Cu}-5 \mathrm{TiB}_{2}$ composites, while the $3 \mathrm{D}$ porosity and particle distribution are shown in Fig. $3 d-f$, $g-i$, respectively. Matrix, particles, and porosity are represented by green, red, and blue colors, respectively. We have separated the porosities and particles from matrix for better visualization. As shown in Fig. 3d-f, porosities increased significantly after hot rolling as well as mushy-state rolling. Table II presents the average equivalent diameter and volume fraction of pores and particles present in the $\mathrm{Al}-4.5 \mathrm{Cu}-5 \mathrm{TiB}_{2}$ composites. As shown by the results in this table, the average equivalent diameter of

\begin{tabular}{|l|lll|}
\hline & Journal : 11837_JOM & Dispatch : 27-2-2019 & Pages : 9 \\
& & $\square$ LE & $\square$ TYPESET \\
& Article No.: $\mathbf{3 3 8 5}$ & $\square$ CP & $\square$ DISK \\
\hline
\end{tabular}


X-Ray Tomography Study on Porosity and Particle Size Distribution in In Situ Al-4.5Cu-5TiB 2 Semisolid Rolled Composites
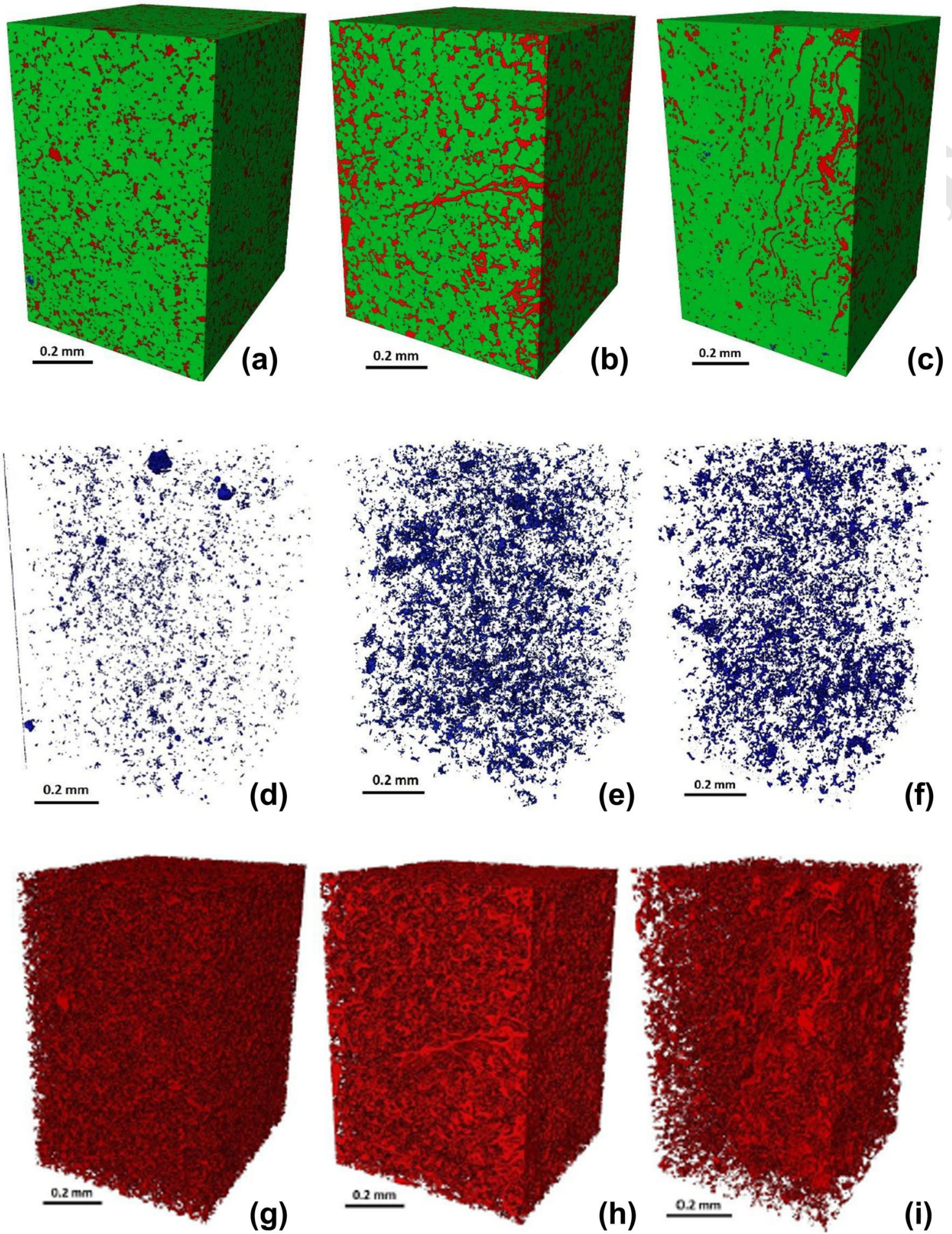

Fig. 3. Segmented volumes of Al-4.5Cu-5TiB 2 composites in (a) as-cast, (b) hot-rolled, and (c) mushy-state-rolled conditions; 3D porosity distribution of Al-4.5Cu-5TiB 2 composites in (d) as-cast, (e) hot-rolled, and (f) mushy-state rolled conditions; 3D particle distribution of $\mathrm{Al}-4.5 \mathrm{Cu}$ $5 \mathrm{TiB}_{2}$ composites in $(\mathrm{g})$ as-cast, (h) hot-rolled, and (i) mushy-state-rolled conditions.

pores in the as-cast composite was $5.6 \mu \mathrm{m}$, increasing to $6.0 \mu \mathrm{m}$ and $8.9 \mu \mathrm{m}$ in the hot-rolled and mushy-state-rolled composites, respectively. Also, the volume fraction of porosity increased from $0.09 \%$ in the as-cast composite to $0.36 \%$ and $0.45 \%$ in the hot-rolled and mushy-state-rolled composites, respectively. Similar observations of an increase in porosity on compressive deformation were made in previous research. Mathew et al. ${ }^{19}$ studied the porosity and particle distribution in semisolid

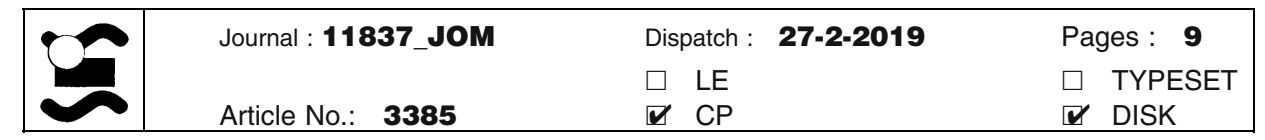


Table II. Average equivalent diameter and volume fraction of pores and particles in $\mathrm{Al}-4.5 \mathrm{Cu}^{-5 \mathrm{TiB}_{2}}$ composites

\begin{tabular}{|c|c|c|c|c|}
\hline $\begin{array}{l}\text { Sample } \\
\text { condition }\end{array}$ & $\begin{array}{c}\text { Average equivalent } \\
\text { diameter of pores (m) }\end{array}$ & $\begin{array}{c}\text { Average equivalent } \\
\text { diameter of particles (m) }\end{array}$ & $\begin{array}{l}\text { Volume fraction of } \\
\text { porosity }(\%) \\
\end{array}$ & $\begin{array}{c}\text { Volume fraction of } \\
\text { particles }(\%)\end{array}$ \\
\hline As-cast & $5.6 \pm 0.5$ & $14.4 \pm 2.3$ & 0.09 & 12.55 \\
\hline Hot rolled & $6.0 \pm 0.3$ & $13.4 \pm 2.3$ & 0.36 & 14.58 \\
\hline Mushy-state rolled & $8.9 \pm 1.2$ & $7.7 \pm 1.1$ & 0.45 & 6.19 \\
\hline
\end{tabular}

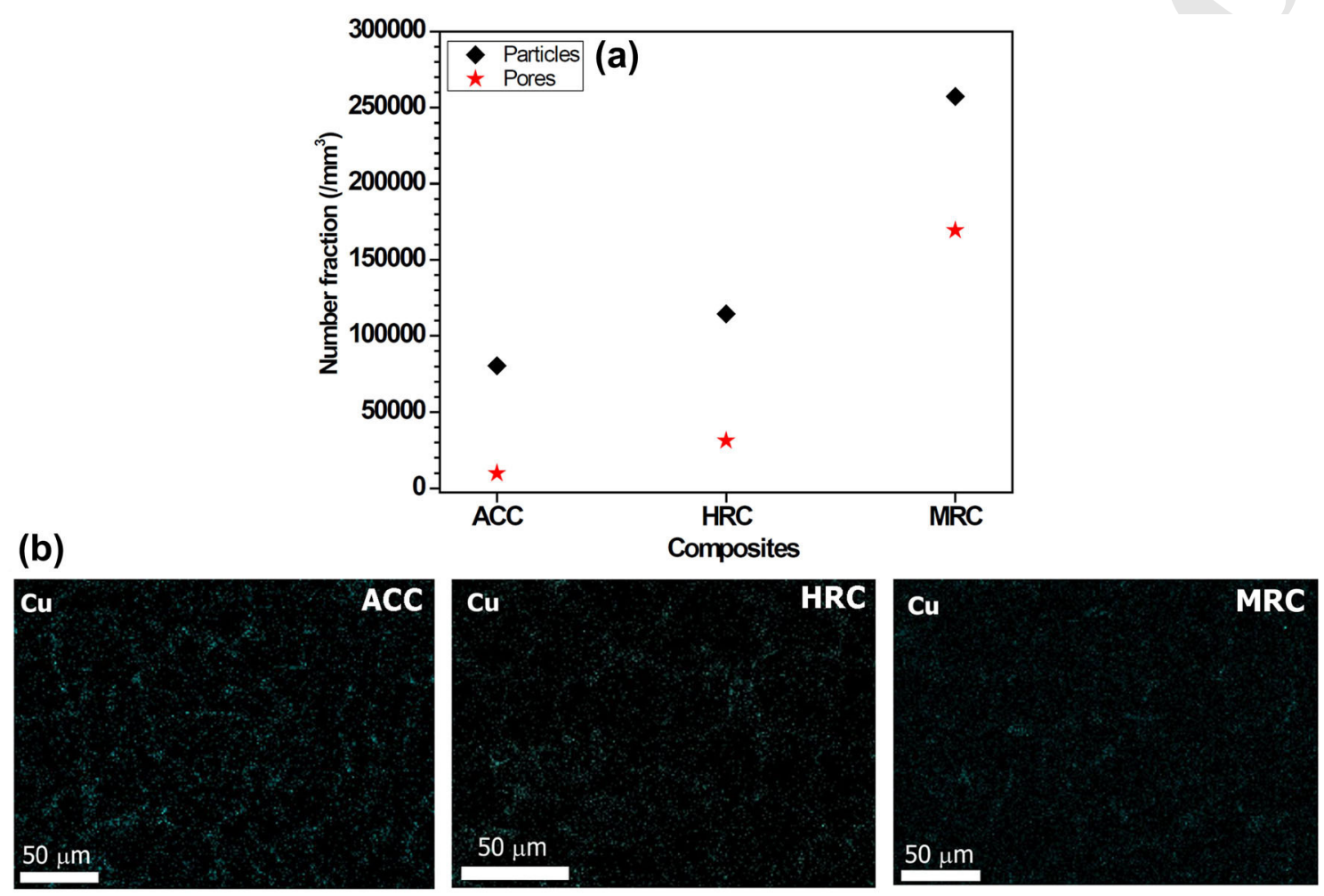

Fig. 4. (a) Number fraction of pores and particles in the $\mathrm{Al}-4.5 \mathrm{Cu}-5 \mathrm{TiB}_{2}$ composite, (b) $\mathrm{Cu}$ distribution in the $\alpha$-Al matrix of the investigated composites.

forged $\mathrm{Al}-\mathrm{Cu}-\mathrm{TiB}_{2}$ composites using XCT, observing an increased porosity in 50\% forged specimen compared with a $30 \%$ forged sample. Kareh et al. ${ }^{41}$ used time-resolved XCT to study the micromechanisms of semisolid metal deformation, observing porosity formation in semisolid alloys with liquid fraction less than $30 \%$. Phillion et al. ${ }^{42}$ studied hot tear damage in $\mathrm{Al}-\mathrm{Mg}$ alloys using XCT and observed strain to be accommodated by the increase in porosity with coalescence of pores at higher strain. Maire et al. ${ }^{43}$ used x-ray microtomography to quantify the intermetallic phases and porosity in Al$\mathrm{Mg}$ industrial alloy, observing a slight increment in porosity on cold rolling. Cai et al. ${ }^{44}$ observed the coalescence of pores and studied the stages of void evolution using in situ synchrotron tomography in semisolid compression of an equiaxed dendritic Al$\mathrm{Cu}$ alloy. In the present study, it was observed that the porosity increased in hot-rolling as well as in mushy-state-rolling conditions. In hot rolling, pores may become elongated, and thereafter come closer to coalesce. In mushy-state rolling, coalescence of pores is possible due to the presence of liquid content, as observed by previous research. ${ }^{41}$

As shown in Fig. $3 \mathrm{~g}-\mathrm{i}$, clusters of $\mathrm{CuAl}_{2}$ and $\mathrm{TiB}_{2}$ particles were densely interconnected in the as-cast composite. Hot rolling resulted in fragmentation of particle clusters, and some of these became elongated, as shown in Fig. 3h. Figure 3i shows the particle distribution in a mushy-state-rolled composite. It is evident from Fig. 3i that mushy-state rolling caused even greater fragmentation of particle clusters compared with hot rolling. Note that some particles are arranged in a river-like pattern in Fig. 3i, as stated above. The average equivalent diameter of $\mathrm{TiB}_{2}-\mathrm{CuAl}_{2}$ particle clusters in the ascast $\mathrm{Al}-4.5 \mathrm{Cu}-5 \mathrm{TiB}_{2}$ composite was found to be $14.4 \mu \mathrm{m}$, compared with $13.4 \mu \mathrm{m}$ and $7.7 \mu \mathrm{m}$ in the

\begin{tabular}{|l|lll|}
\hline & Journal : 11837_JOM & Dispatch : 27-2-2019 & Pages : $\mathbf{9}$ \\
& & $\square$ LE & $\square$ TYPESET \\
& Article No.: $\mathbf{3 3 8 5}$ & $\square \mathrm{CP}$ & $\varangle$ DISK \\
\hline
\end{tabular}


X-Ray Tomography Study on Porosity and Particle Size Distribution in In Situ Al-4.5Cu-5TiB 2 Semisolid Rolled Composites
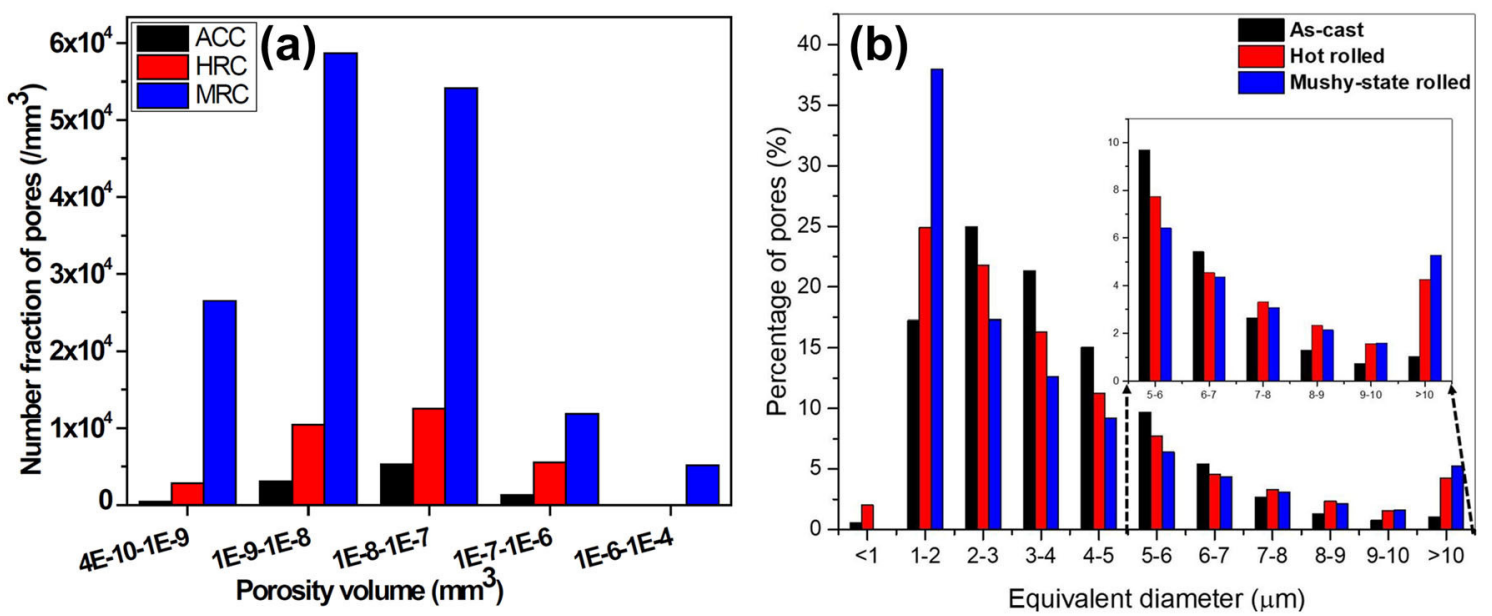

Fig. 5. Quantified size distribution of porosity presented as (a) number fraction versus volume and (b) percentage in Al-4.5Cu-5TiB 2 composites.
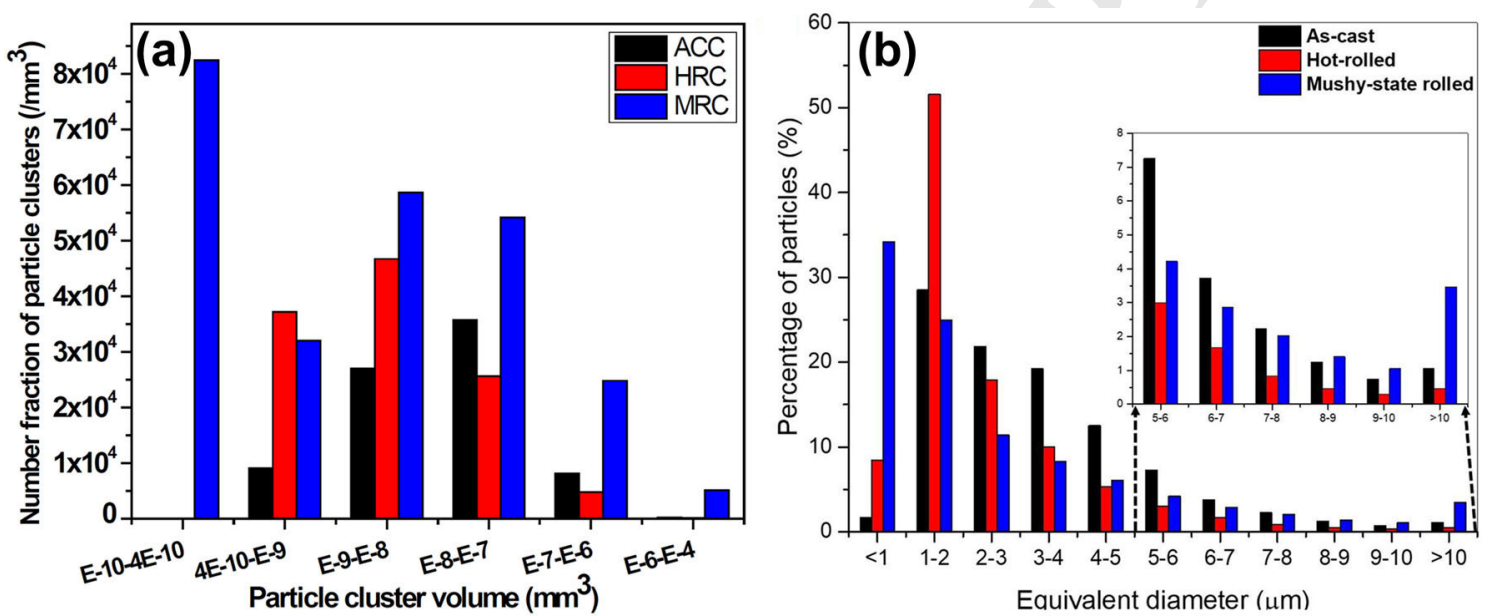

Fig. 6. Quantified size distribution of particles represented as (a) number fraction versus volume and (b) percentage in $\mathrm{Al}-4.5 \mathrm{Cu}-5 \mathrm{TiB}{ }_{2}$ composite.

hot-rolled and mushy-state-rolled composites, respectively (Table II). As discussed above, multiple phenomena may be responsible for this. Particles can act as stress concentration sites which can break above a threshold value of the compressive stress applied in hot rolling. In mushy-state rolling, the presence of liquid fraction is beneficial, as liquid formed near the grain boundaries can pull $\mathrm{TiB}_{2}$ particles by capillary forces, resulting in their redistribution along with distribution of the soluterich liquid. The particle distribution results observed in the present work are consistent with the classical hypothesis that semisolid processing results in a reduction in cluster size and redistribution of $\mathrm{TiB}_{2}$ particles. $^{3,5,6}$ Mathew et al. ${ }^{19}$ observed a more homogeneous distribution of $\mathrm{TiB}_{2}$ particles in semisolid forged $\mathrm{Al}-4.5 \mathrm{Cu}-5 \mathrm{TiB}_{2}$ composite using XCT.

The results for the porosity and particle size obtained by XCT are quantified and plotted in Figs. 4, 5 , and 6 . Figure 4 a depicts the number of particle clusters and pores per unit volume. From Table II, it can be seen that the volume fraction of particles is lowest after mushy-state rolling, which can be attributed to solutionization of $\mathrm{CuAl}_{2}$ particles in the eutectic mixture at the elevated temperature. Figure $4 \mathrm{~b}$ shows EDAX maps of the $\mathrm{Cu}$ atom distribution of ACC, HRC, and MRC, revealing that the highest $\mathrm{Cu}$ distribution in the solid solution is observed for MRC, hence justifying the lowering of the particle cluster volume fraction in this case. As shown in Fig. 4a, the number fraction of both pores and particles increased in hot-rolled as well as in mushy-state-rolled composites, which primarily suggests the fragmentation of existing cluster size.

Figure 5 presents the size distribution of the porosity in the composites for the three different processing conditions. Figure 5a shows the number fraction of pores having different volumes ranging from $4 \times 10^{-10} \mathrm{~mm}^{3}$ to $1 \times 10^{-4} \mathrm{~mm}^{3}$. MRC shows the highest number fraction of pores over the entire volume range, as depicted in Fig. 5a. As shown in

\begin{tabular}{|l|lll|}
\hline & Journal : 11837_JOM & Dispatch : 27-2-2019 & Pages : 9 \\
& & $\square$ LE & $\square$ TYPESET \\
\hline Article No.: $\mathbf{3 3 8 5}$ & $\square \mathrm{CP}$ & $\square$ DISK \\
\hline
\end{tabular}


361 Fig. 5a, both the hot-rolled and mushy-state-rolled 362 composites contained a higher number of small-size 363 as well as large-size pores as compared with the as364 cast composite. Such a high number fraction of 365 small-size pores in the MRC might have formed at 366 the time of solidification of the solute-rich liquid in 367 the mushy-state rolling process. The difference in 368 coefficient of thermal expansion between various

phases may have accelerated the formation of the very fine-sized shrinkage porosity during quenching. Figure $5 \mathrm{~b}$ presents the size distribution of pores in the form of percentages. As shown in Fig. 5b, the hot-rolled and mushy-state-rolled composites contained $25 \%$ and $38 \%$ of pores having equivalent diameter in the range of $1 \mu \mathrm{m}$ to $2 \mu \mathrm{m}$, as compared with $17 \%$ for the as-cast composite. However, at the same time, $12 \%$ of pores had equivalent diameter greater than $7 \mu \mathrm{m}$ in the hot-rolled as well as mushy-state-rolled composites, as shown in Fig. 5b. However, the as-cast composite contained only $6 \%$ of pores with equivalent diameter greater than $7 \mu \mathrm{m}$. These results suggest that formation of porosity, annihilation of porosity, and coalescence of pores are the competitive phenomena occurring during secondary processing. In situ XCT study is required to understand the mechanism of porosity formation in the secondary processing of these composites.

Figure 6 presents the quantified distribution of particle cluster size in the as-cast as well as rolled $\mathrm{Al}-4.5 \mathrm{Cu}-5 \mathrm{TiB}_{2}$ composites. Figure $6 \mathrm{a}$ shows the number fraction of the same against the volume ranging from $1 \times 10^{-10} \mathrm{~mm}^{3}$ to $1 \times 10^{-4} \mathrm{~mm}^{3}$. It is evident from the graphs presented in Fig. $6 \mathrm{a}$ that the highest number fraction of the finest particle clusters (volume range $1 \times 10^{-10} \mathrm{~mm}^{3}$ to $4 \times$ $10^{-10} \mathrm{~mm}^{3}$ ) are present exclusively in the mushystate-rolled composite. Careful observation of Fig. 6a suggests that the mushy-state-rolled composite also contained a higher number fraction of the largest size particles having volume in the range of $1 \times 10^{-6} \mathrm{~mm}^{3}$ to $1 \times 10^{-4} \mathrm{~mm}^{3}$ as compared with the as-cast or hot-rolled composite. This indicates that a broad range of particle clusters formed during mushy-state rolling. At the time of mushy-state rolling, the solute $(\mathrm{Cu})$-enriched liquid squeezed out nonuniformly from the interdendritic regions due to the compressive force at the time of mushy-state rolling, and the $\mathrm{TiB}_{2}$ particles were dragged along with the liquid, which is again evident from the SEM images shown in Fig. 1. Thus, the presence of very fine-sized particle clusters in a significant number fraction can be justified. On the other hand, the solidification of the solute-rich liquid at some of the intergranular locations due to the mushy-state rolling process might have led to the highest number fraction of large-size particles.

Figure $6 \mathrm{~b}$ shows the size distribution of particles in the form of percentage. As shown in Fig. 6b, the mushy-state-rolled composite contained $34 \%$ of particles including both $\mathrm{TiB}_{2}$ and $\mathrm{CuAl}_{2}$ having equivalent diameter less than $1 \mu \mathrm{m}$. The hot-rolled and as-cast composites exhibited $9 \%$ and $2 \%$ of particle clusters with similar equivalent diameter, respectively. Furthermore, both the mushy-staterolled and hot-rolled composites contained $40 \%$ of particle clusters with equivalent diameter greater than $2 \mu \mathrm{m}$. On the other hand, $71 \%$ of particles in the as-cast composite had equivalent diameter above $2 \mu \mathrm{m}$. These quantitative data support the results obtained by qualitative analysis that hot rolling and mushy-state rolling both influence the size reduction and redistribution of $\mathrm{CuAl}_{2}-\mathrm{TiB}_{2}$ clusters, with mushy-state rolling having a greater impact compared with hot rolling.

The present XCT study of the porosity and particle size distribution in $\mathrm{Al}-4.5 \mathrm{Cu}-5 \mathrm{TiB}_{2}$ composites suggests that secondary processing such as mushystate rolling and hot rolling can help to fragment $\mathrm{CuAl}_{2}-\mathrm{TiB}_{2}$ particle clusters located at grain boundaries and triple-grain junctions and results in a more homogeneous distribution over the matrix. The significant increment of the finest porosity in the mushy-state-rolled composite seems to be related to quick solidification of the solute-rich liquid at the time of mushy-state rolling. More advanced and detailed study, e.g., using in situ x-ray tomography techniques, is further required for better understanding of the pores and particle distribution within the microstructure. The quantitative information on the porosity and $\mathrm{TiB}_{2}$ particle size distribution obtained in the present work can provide a new direction for the choice of secondary processing routes and help modeling of the mechanical performance of $\mathrm{Al}-4.5 \mathrm{Cu}-5 \mathrm{TiB}_{2}$ composites.

\section{CONCLUSION}

- The $\mathrm{CuAl}_{2}-\mathrm{TiB}_{2}$ particle cluster distribution results show that both hot and mushy-state rolling helped further fragmentation and redistribution. The large particle clusters in the as-cast microstructure were crushed to smaller size due to the compressive action of the rollers. Additionally, the presence of the solute-rich liquid helped in dragging the $\mathrm{TiB}_{2}$ particles and redistributing them more evenly in the liquid state compared with the hot-rolled composite. Some large clusters were occasionally observed in MRC due to the nonuniform initial cast microstructure.

- The very fine-sized porosity observed with large number fraction for the case of MRC is associated with quick solidification of the solute-rich liquid during the mushy-state rolling process.

\section{OPEN ACCESS}

This article is distributed under the terms of the Creative Commons Attribution 4.0 International License (http://creativecommons.org/licenses/by/4.0/ ), which permits unrestricted use, distribution, and reproduction in any medium, provided you give

\begin{tabular}{|l|lll|}
\hline & Journal : 11837_JOM & Dispatch : 27-2-2019 & Pages : 9 \\
& & $\square$ LE & $\square$ TYPESET \\
\hline Article No.: $\mathbf{3 3 8 5}$ & $\square \mathrm{CP}$ & $\square$ DISK \\
\hline
\end{tabular}


X-Ray Tomography Study on Porosity and Particle Size Distribution in In Situ Al-4.5Cu-5TiB 2 Semisolid Rolled Composites

481 appropriate credit to the original author(s) and the

source, provide a link to the Creative Commons license, and indicate if changes were made.

\section{REFERENCES}

1. G.S. Cole and A.M. Sherman, Mater Charact 35, 3 (1995).

2. C.S. Lee, Y.H. Kim, K.S. Han, and T. Lim, J Mater Sci 27, 793 (1992).

3. K. Pavitra and R. Mitra, Mater Sci Eng, A 557, 84 (2012).

4. A. Jana, I.G. Siddhalingeshwar, and R. Mitra, Mater Sci Eng, A 575, 104 (2013).

5. I.G. Siddhalingeshwar, M.A. Herbert, M. Chakraborty, and R. Mitra, Mater Sci Eng, A 528, 1787 (2011).

6. M. Mandal and R. Mitra, JOM 68, 1902 (2016).

7. J. Mathew, A. Mandal, S.D. Kumar, S. Bajpai, M. Chakraborty, G.D. West, and P. Srirangam, J. Alloys Compd. 712, 460 (2017).

8. M. Emamy, M. Mahta, and J. Rasizadeh, Compos. Sci. Technol. 66, 1063 (2006).

9. M.A. Herbert, R. Maiti, R. Mitra, and M. Chakraborty, Solid State Phenom 116-117, 217 (2006).

10. D.J. Lloyd, Int Mater Rev 39, 1 (1994).

11. K.K. Chawla and N. Chawla, Metal matrix composites: automotive applications.Encyclopedia of Automotive Engineering, ed. D. Crolla, D.E. Foster, T. Kobayashi, and N. Vaughan (Chichester: Wiley, 2014), p. 1.

12. M. Karbalaei Akbari, H.R. Baharvandi, and K. Shirvanimoghaddam, Mater Des 66, 150 (2015).

13. V. Milman and M.C. Warren, J Phys: Condens Matter 13 5585 (2001).

14. R.G. Munro, J. Res. Natl. Inst. Stand. Technol. 105, 709 (2000).

15. H. Abdizadeh, H.R. Baharvandi, and K.S. Moghaddam, Mater Sci Eng, A 498, 53 (2008).

16. B.S. Murty, S.A. Kori, and M. Chakraborty, Int Mater Rev 47, 3 (2002).

17. F. Chen, F. Mao, Z. Chen, J. Han, G. Yan, T. Wang, and Z. Cao, J. Alloys Compd. 622, 831 (2015).

18. I.A. Ibrahim, F.A. Mohamed, and E.J. Lavernia, J Mater Sci 26, 1137 (1991)

19. J. Mathew, A. Mandal, J. Warnett, M.A. Williams, M. Chakraborty, and P. Srirangam, Mater Charact 118, 57 (2016).

20. J. Geng, T. Hong, Y. Shen, G. Liu, C. Xia, D. Chen, M. Wang, and H. Wang, Mater Charact 124, 50 (2017).

21. J. Nie, F. Wang, Y. Li, Y. Liu, X. Liu, and Y. Zhao, Trans Nonferrous Met Soc China 27, 2548 (2017).

22. S. Gourdet and F. Montheillet, Mater Sci Eng, A 283, 274 (2000).

23. T. Sakai, H. Miura, A. Goloborodko, and O. Sitdikov, Acta Mater 57, 153 (2009).
24. J. Wannasin, R. Canyook, S. Wisutmethangoon, and M.C. Flemings, Acta Mater 61, 3897 (2013).

25. A.A. Tseng, J. Horskỳ, M. Raudenskỳ, and P. Kotrbacek, Mater Des 22, 83 (2001).

26. I.G. Siddhalingeshwar, D. Deepthi, M. Chakraborty, and R. Mitra, Wear 271, 748 (2011).

27. M.A. Herbert, G. Das, R. Maiti, M. Chakraborty, and R. Mitra, Int J Cast Met Res 23, 216 (2010).

28. N.C. Chapman, J. Silva, J.J. Williams, N. Chawla, and X. Xiao, Mater Sci Technol 31, 573 (2015).

29. J.J. Williams, N.C. Chapman, V. Jakkali, V.A. Tanna, N. Chawla, X. Xiao, and F. De Carlo, Metall Mater Trans A 42, 2999 (2011).

30. A. Ferre, S. Dancette, and E. Maire, Mater Sci Technol 31, 579 (2015).

31. J.J. Williams, Z. Flom, A.A. Amell, N. Chawla, X. Xiao, and F. De Carlo, Acta Mater 58, 6194 (2010).

32. I.G. Watson, M.F. Forster, P.D. Lee, R.J. Dashwood, R.W. Hamilton, and A. Chirazi, Compos. Part Appl. Sci. Manuf. 36, 1177 (2005).

33. L. Babout, Y. Brechet, E. Maire, and R. Fougères, Acta Mater 52, 4517 (2004).

34. E. Maire and P.J. Withers, Int Mater Rev 59, 1 (2014).

35. F. de Andrade Silva, J.J. Williams, B.R. Müller, M.P. Hentschel, P.D. Portella, and N. Chawla, Metall Mater Trans A 41, 2121 (2010).

36. P.M. Mummery, B. Derby, P. Anderson, G.R. Davis, and J. C. Elliott, J Microsc 177, 399 (1995).

37. S. Terzi, R. Daudin, J. Villanova, P. Srirangam, P. Lhuissier, L. Salvo, E. Boller, R. Schweins, P. Lindner, and J.-J. Blandin, X-ray tomography and small-angle neutron scattering characterization of nano-composites: static and in situ experiments.Light Metals, ed. J. Grandfield (Berlin: Springer, 2014), p. 1389.

38. M. De Giovanni, J.M. Warnett, M.A. Williams, N. Haribabu, and P. Srirangam, Mater Charact 110, 258 (2015).

39. R.W. Hamilton, M.F. Forster, R.J. Dashwood, and P.D. Lee, Scr. Mater. 46, 25 (2002).

40. M. Mandal and R. Mitra, Mater Charact 146, 267 (2018).

41. K.M. Kareh, P.D. Lee, R.C. Atwood, T. Connolley, and C.M. Gourlay, Nat. Commun. 5, 4464 (2014).

42. A.B. Phillion, S.L. Cockcroft, and P.D. Lee, Scr. Mater. 55, 489 (2006).

43. E. Maire, J. Grenier, D. Daniel, A. Baldacci, H. Klocker, and A. Bigot, Scr. Mater. 55, 123 (2006).

44. B. Cai, S. Karagadde, L. Yuan, T.J. Marrow, T. Connolley, and P.D. Lee, Acta Mater 76, 371 (2014).

Publisher's Note Springer Nature remains neutral with regard to jurisdictional claims in published maps and institutional affiliations.

\begin{tabular}{|l|lll|}
\hline \multirow{2}{*}{ Journal : 11837_JOM } & Dispatch : 27-2-2019 & Pages : $\mathbf{9}$ \\
& & $\square$ LE & $\square$ TYPESET \\
& Article No.: $\mathbf{3 3 8 5}$ & $\square \mathrm{CP}$ & $\varangle$ DISK \\
\hline
\end{tabular}


Journal : 11837

Article : 3385

\section{Author Query Form}

\section{Please ensure you fill out your response to the queries raised below and return this form along with your corrections}

\section{Dear Author}

During the process of typesetting your article, the following queries have arisen. Please check your typeset proof carefully against the queries listed below and mark the necessary changes either directly on the proof/online grid or in the 'Author's response' area provided below

\begin{tabular}{|c|c|c|}
\hline Query & Details Required & Author's Response \\
\hline AQ1 & $\begin{array}{l}\text { Please confirm that the author names are presented accurately and in the correct sequence (given names/ } \\
\text { initials, family name). }\end{array}$ & \\
\hline AQ2 & Kindly check and confirm that the edit made in the title is correct. & \\
\hline AQ3 & Please confirm the abbreviation "SEM" definition added on first use for completeness. & \\
\hline AQ4 & $\begin{array}{l}\text { Journal instruction requires a city (Kharagpur and Coventry) and country (India and UK) for affiliations. } \\
\text { Please verify if the provided city and country are correct and amend if necessary. }\end{array}$ & \\
\hline AQ5 & Please confirm the abbreviation "EBSD" definition added on first use for completeness. & \\
\hline AQ6 & $\begin{array}{l}\text { As References [32] and [40] are same, we have deleted the duplicate reference and renumbered accordingly. } \\
\text { Please check and confirm. }\end{array}$ & \\
\hline
\end{tabular}

